\title{
Rehydration Characteristics of Dehydrated Different Onion Slices
}

\author{
Goudra Pramod Gouda*, C.T. Ramachandra, Udaykumar Nidoni, \\ H. Sharanagouda, P.F. Mathad and R.S. Roopa Bai
}

\begin{abstract}
Department of Processing and Food Engineering, College of Agricultural Engineering, University of Agricultural Sciences, Raichur 584 104, Karnataka, India

*Corresponding author
\end{abstract}

\section{A B S T R A C T}

\section{Keywords}

Arka kalyan, Bijapur white, Arka pragati, Pretreatment, Drying, Rehydration ratio.

Article Info

Accepted:

23 September 2017

Available Online:

10 October 2017
The present work was aimed to study the rehydration characteristics of dehydrated different onion slices namely, Arka kalyan, Bijapur white and Arka pragati which were dried under open yard sun drying, solar tunnel drying and dehumidified air drying methods. The onions were pre-treated with $10 \%$ sodium chloride $(\mathrm{NaCl})$ for $1 \mathrm{~h}, 0.2 \%$ potassium metabisulphite (KMS) for 15 minutes and both $10 \%$ sodium chloride $(\mathrm{NaCl})+$ $0.2 \%$ potassium metabisulphite (KMS) for 15 minutes at room temperature before drying. Rehydration experiments was conducted with three different temperatures $(25,45$ and 65 ${ }^{\circ} \mathrm{C}$ ), It was revealed from the results that, the dehumidified air dried, untreated Bijapur white onion had higher rehydration ratio of 5.08 followed by dehumidified air dried, untreated Arka pragati and Arka kalyan onion was 5.07 and 5.06 at $65{ }^{\circ} \mathrm{C}$ as compared other two temperatures. The pretreatment resulted in a decrease in the diffusion coefficient of water as well as an increase in the diffusion coefficient of solute during rehydration. Decrease in the diffusion coefficient of water was due to an increase in the proportion of ruptured and shrunken cells caused by osmotic treatments, which in turn resulted in reduced ability of dried onion tissue to absorb water. The increase in diffusion coefficient for solid during rehydration was higher in the case of osmotic pre-treated material, some of the solids absorbed during osmotic dehydration were not retained in the cell matrix and dissolve faster than the constitutive onion dry matter.

\section{Introduction}

Onion (Allium cepa L.), one of the main crops under Allium family, cultivated mainly in the tropical countries since long time. Besides imparting a characteristic taste and flavour to food, it also has significant therapeutic values (Augusti, 1996). Onion serves as a good medicinal compound for cataract, cardiovascular disease and cancer due to its hypocholesterolemic, thrombolitic and antioxidant effects (Block et al., 1997; Nuutila et al., 2003 and Stavric, 1997).
It has been in cultivation for more than 4000 years (Brewster, 1994). Onion contains vitamin $B$ and a trace of vitamin $C$ and also traces of iron and calcium. The outstanding characteristic of onion is its pungency, which is due to a volatile oil known as allyl-propyl disulphide. Onions when compared with other fresh vegetables are relatively high in food energy, intermediate in protein content and rich in calcium and riboflavin. Dehydrated onion can be used in many processed or 
ready-to-eat foods in place of raw onion. This has several advantages such as convenience of transportation, storage, preparation and use (Mazza and Le Maguer, 1980; Lewicki et al., 1998). It is marketed in various forms, such as sliced, flaked, minced, chopped and powdered.

It is also used as a flavouring additive in several products in food industries such as meat products, sauces, soups, salad dressings, pickles and other snack items (Adam et al., 2000). Dehydrated products need to be rehydrated before consumption or further processing (Oliveira and Ilincanu, 1999). Drying of fruit and vegetables by different methods has been extensively studied. During rehydration, absorption of water into the tissue results in an increase in the mass. Simultaneously, leaching out of solute (sugars, acids, minerals, vitamins) also occurs and both phenomena are influenced by the nature of the product and conditions employed for rehydration (Lewicki, 1998).

Rehydration of onion has been studied by many researchers (Adam et al., 2000) and results were expressed in terms of rehydration capacity, rehydration ratio or reconstitution ratio. Andreotti et al., (1981) compared rehydration properties of freeze-dried onion slices with those of dried onion prepared by partially air-drying followed by freeze-drying.

They found that freeze-dried samples had better rehydration capacity and the rate of rehydration increased with temperature of rehydration. Drying of fruit and vegetables by different methods has been extensively studied, but there is little information available related to the rehydration of the dried products. Hence, the aim of the present work was taken to investigate the effect of pre-treatments, drying methods on rehydration characteristics of dried onion of different varieties.

\section{Materials and Methods}

\section{Sample preparation}

Three varieties of fresh onions viz., Arka kalyan, Bijapur white and Arka pragati were procured from two different production catchments namely, Bijapur and Chikkaballapur in Karnataka. Care was taken to select good quality onions by considering the factors like size, shape and freedom from physical damage.

The onion bulbs were then thoroughly cleaned to remove any dirt or dust particles attached to the surface. The cleaned onions were peeled and the roots were cut with a sharp stainless steel knife and peeled onion bulbs were washed with $1 \%$ sodium hypochloride solution to avoid infestation. Onions were sliced using a power operated onion slicer into slices of 2 to $5 \mathrm{~mm}$ thickness.

The onion slices were weighed and dipped in $10 \%$ sodium chloride $(\mathrm{NaCl})$ for $1 \mathrm{~h}$ (as a preservative) (Debnath et al., 2004) and 0.2\% potassium metabisulphite (KMS) for 15 minutes (as an antifungal) (Mitra et al., 2011). The onion slices were also dipped in both $10 \%$ sodium chloride $(\mathrm{NaCl})+0.2 \%$ potassium metabisulphite (KMS) for 15 minutes at room temperature.

After pre-treatment, onion slices were drained for $5 \mathrm{~min}$ to remove surface moisture (Kadam et al., 2008). Then the pretreated onion slices of $5 \mathrm{~kg}$ weight was spread in each tray and dried in open yard sun drying, solar tunnel drying and dehumidified air drying $\left(50 \pm 1{ }^{\circ} \mathrm{C}\right.$ and $15 \pm 1 \% \mathrm{RH}$ ) from initial moisture content of $86 \%$ (w.b.) to $5 \%$ (d.b.) of final moisture content. 1:25. the dehydrated onion slices were packed in polyethelene packaging material and stored in ambient temperature for rehydration studies. 


\section{Rehydration ratio}

This is one of the important parameter for determination of quality of dehydrated product. $50 \mathrm{~g}$ of dehydrated onion samples were tied in muslin cloth and dipped in distilled water at 25,45 and $65{ }^{\circ} \mathrm{C}$. The ratio of the weight of onion slices to that of medium (water) was maintained at 1:25.

The rehydration ratio of onion sample was estimated as per AOAC (1990) procedure. The sample weight before and after rehydration was calculated and from these rehydration ratio was determined as follows:

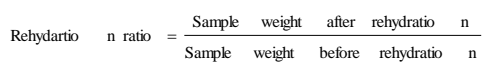

\section{Statistical analysis}

The experiment was carried out in three factorial Complete Randomised block Design (CRD) with three replications. After proper analysis, data were accommodated in the tables as per the needs of objective for interpretation of results. The Microsoft office excels (2007) was used for analysis and interpretation. The statistical procedures for agricultural research given by Gomez and Gomez (1976) were referred

\section{Results and Discussion}

\section{Rehydration characteristics of dehydrated onion slices}

Effect of different pre-treatments and drying methods on rehydration ratio of dehydrated onion slices rehydrated at 25 ${ }^{\circ} \mathrm{C}$

The rehydration ratio of Arka kalyan, Bijapur white and Arka pragati onion dried under different drying methods and pre-treatments were observed. The data obtained was analysed statistically and the individual factors i.e. drying methods and pretreatments, combined effect i.e. drying method and pretreatment was found to be significant at $1 \%$ level $(\mathrm{P}<0.01)$ and the effect of different drying methods, varieties and pre-treatments on rehydration ratio rehydrated at $25{ }^{\circ} \mathrm{C}$ is depicted in Figure 1.

It is observed that in open yard sun drying, the rehydration ratio of Arka kalyan, Bijapur white and Arka pragati onion was varied from 2.83-4.09, 2.85-4.12 and 2.83-4.11 among the different pre-treatments. Similarly in solar tunnel drying, the rehydration ratio of Arka kalyan, Bijapur white and Arka pragati onion was varied from 2.90-4.61, 2.91-4.63 and 2.90-4.60, respectively. In case of dehumidified air drying, the rehydration ratio of Arka kalyan, Bijapur white and Arka pragati onion was varied from 2.95-4.91, 2.97-4.93 and 2.96-4.92, respectively.

The data indicated that open yard sun drying, pre-treated with $10 \% \mathrm{NaCl}$ of Arka pragati and Arka kalyan onion had lowest rehydration ratio of 2.83 compared with all other treatments (Table 1) because during rehydration, the absorbed salt might have been dissolved in water, which decreased the weight of the sample and hence reduced the rehydration ratio (Sutar et al., 2007).

This variation might be due to an increase in the proportion of ruptured and shrunken cells caused by pre-treatment which in turn reduced the ability of dried onion tissues to absorb water. As temperature increased, the rehydration ratio increased slightly resulting in a proportional increase in the rehydration efficiency. This is because the faster drying in dehumidified air drying caused less damage to the cells and as a consequence the water absorption efficiency was more as reported by Debnath et al., (2004). Similar results were obtained by Mitra et al., (2011) who reported that rehydration ratio was more in case of 
untreated samples i.e. the rehydration efficiency of untreated onion slices was more than that of brined onion slices.

Effect of different pre-treatments and drying methods on rehydration ratio of dehydrated onion slices rehydrated at 45 ${ }^{\circ} \mathrm{C}$

The rehydration ratio of Arka kalyan, Bijapur white and Arka pragati onion dried under different drying methods and pre-treatments were observed. The data obtained was analysed statistically $(\mathrm{P}<0.01)$ and the effect of different drying methods, varieties and pre- treatments on rehydration ratio rehydrated at $45{ }^{\circ} \mathrm{C}$ is depicted in Figure 2. It is observed that in open yard sun drying, the rehydration ratio of Arka kalyan, Bijapur white and Arka pragati onion was varied from 2.89-4.43, 2.90-4.46 and 2.89-4.43 among the different pre-treatments. Similarly in solar tunnel drying, the rehydration ratio of Arka kalyan, Bijapur white and Arka pragati onion was varied from 2.96-4.79, 2.97-4.81 and 2.954.80 , respectively. In case of dehumidified air drying, the rehydration ratio of Arka kalyan, Bijapur white and Arka pragati onion was varied from 3.19-4.97, 3.21-4.99 and 3.204.97, respectively.

Table.1 Rehydration ratio of dehydrated onion slices obtained from different drying methods, varieties and pre-treatments rehydrated at $25^{\circ} \mathrm{C}$

\begin{tabular}{|c|c|c|c|c|c|c|c|}
\hline \multirow{2}{*}{$\begin{array}{l}\text { Drying } \\
\text { methods }\end{array}$} & \multirow{2}{*}{ Varieties } & \multicolumn{6}{|c|}{ Pre-treatments } \\
\hline & & $\mathbf{P}_{1}$ & & $\mathbf{P}_{2}$ & $\mathbf{P}_{\mathbf{3}}$ & & $\mathbf{P}_{4}$ \\
\hline \multirow{3}{*}{$\mathrm{D}_{1}$} & $\mathrm{~V}_{1}$ & 4.09 & & 2.83 & 3.40 & & 2.87 \\
\hline & $\mathrm{V}_{2}$ & 4.12 & & 2.85 & 3.43 & & 2.88 \\
\hline & $\mathrm{V}_{3}$ & 4.11 & & 2.83 & 3.41 & & 2.88 \\
\hline \multirow{3}{*}{$\mathrm{D}_{2}$} & $\mathrm{~V}_{1}$ & 4.61 & & 2.90 & 3.58 & & 2.95 \\
\hline & $\mathrm{V}_{2}$ & 4.63 & & 2.91 & 3.60 & & 2.97 \\
\hline & $\mathrm{V}_{3}$ & 4.60 & & 2.90 & 3.58 & & 2.96 \\
\hline \multirow{3}{*}{$\mathrm{D}_{3}$} & $\mathrm{~V}_{1}$ & 4.91 & & 2.95 & 3.68 & & 3.08 \\
\hline & $\mathrm{V}_{2}$ & 4.93 & & 2.97 & 3.72 & & 3.09 \\
\hline & $\mathrm{V}_{3}$ & 4.92 & & 2.96 & 3.69 & & 3.07 \\
\hline $\begin{array}{l}\text { Source of } \\
\text { variation }\end{array}$ & $\begin{array}{c}\text { Degrees of } \\
\text { freedom }\end{array}$ & $\begin{array}{l}\text { Mean sum } \\
\text { of squares }\end{array}$ & $\begin{array}{c}\text { Mean } \\
\text { squares }\end{array}$ & F-cal & F-table & SEm \pm & $\begin{array}{c}\text { CD@ } \\
1 \%\end{array}$ \\
\hline Total & 107 & 51.87 & & & & & \\
\hline Error & 72 & 1.27 & 0.017 & \multirow[b]{2}{*}{$65.10 * *$} & & & \\
\hline $\mathrm{D}$ & 2 & 2.30 & 1.15 & & 4.91 & 0.02 & 0.08 \\
\hline V & 2 & 0.01 & 0.00 & $0.24 \mathrm{NS}$ & 4.91 & 0.02 & 0.08 \\
\hline $\mathrm{P}$ & 3 & 46.93 & 15.64 & $885.56 * *$ & 4.07 & 0.03 & 0.10 \\
\hline $\mathrm{D} \times \mathrm{V}$ & 4 & 0.00 & 0.00 & $0.00 \mathrm{NS}$ & 3.59 & 0.04 & 0.14 \\
\hline $\mathrm{D} \times \mathrm{P}$ & 6 & 1.36 & 0.23 & $12.84 * *$ & 3.06 & 0.04 & 0.17 \\
\hline $\mathrm{V} \times \mathrm{P}$ & 6 & 0.00 & 0.00 & $0.01 \mathrm{NS}$ & 3.06 & 0.04 & 0.17 \\
\hline $\mathrm{D} \times \mathrm{V} \times \mathrm{P}$ & 12 & 0.00 & 0.00 & $0.01 \mathrm{NS}$ & 2.44 & 0.08 & 0.29 \\
\hline \multicolumn{2}{|c|}{ ** Significant at $1 \%$ level } & \multicolumn{3}{|c|}{ NS - Non Significant } & & & \\
\hline \multicolumn{2}{|c|}{$\mathrm{D}_{1}$ : Open Yard Sun Drying } & \multirow{2}{*}{\multicolumn{3}{|c|}{$\begin{array}{l}\mathrm{D}_{2}: \text { Solar Tunnel Dryer } \\
\mathrm{V}_{2}: \text { Bijapur white (White) }\end{array}$}} & Dehumidi & fied Air & Dryer \\
\hline \multicolumn{2}{|c|}{$\mathrm{V}_{1}$ : Arka kalyan $(\mathrm{Red})$} & & & & Arka prag & ati (Pink & \\
\hline \multicolumn{2}{|c|}{$\mathrm{P}_{1}:$ Untreated (Control) } & \multicolumn{6}{|c|}{$\mathrm{P}_{2}: 10 \% \mathrm{NaCl}$ for $1 \mathrm{~h}$} \\
\hline $\mathrm{P}_{3}: 0.2 \% \mathrm{~K}$ & IS for $15 \mathrm{~min}$ & \multicolumn{6}{|c|}{$\mathrm{P}_{4}: 10 \% \mathrm{NaCl}+0.2 \% \mathrm{KMS}$ for $15 \mathrm{~min}$} \\
\hline
\end{tabular}


Table.2 Rehydration ratio of dehydrated onion slices obtained from different drying methods, varieties and pre-treatments rehydrated at $45^{\circ} \mathrm{C}$

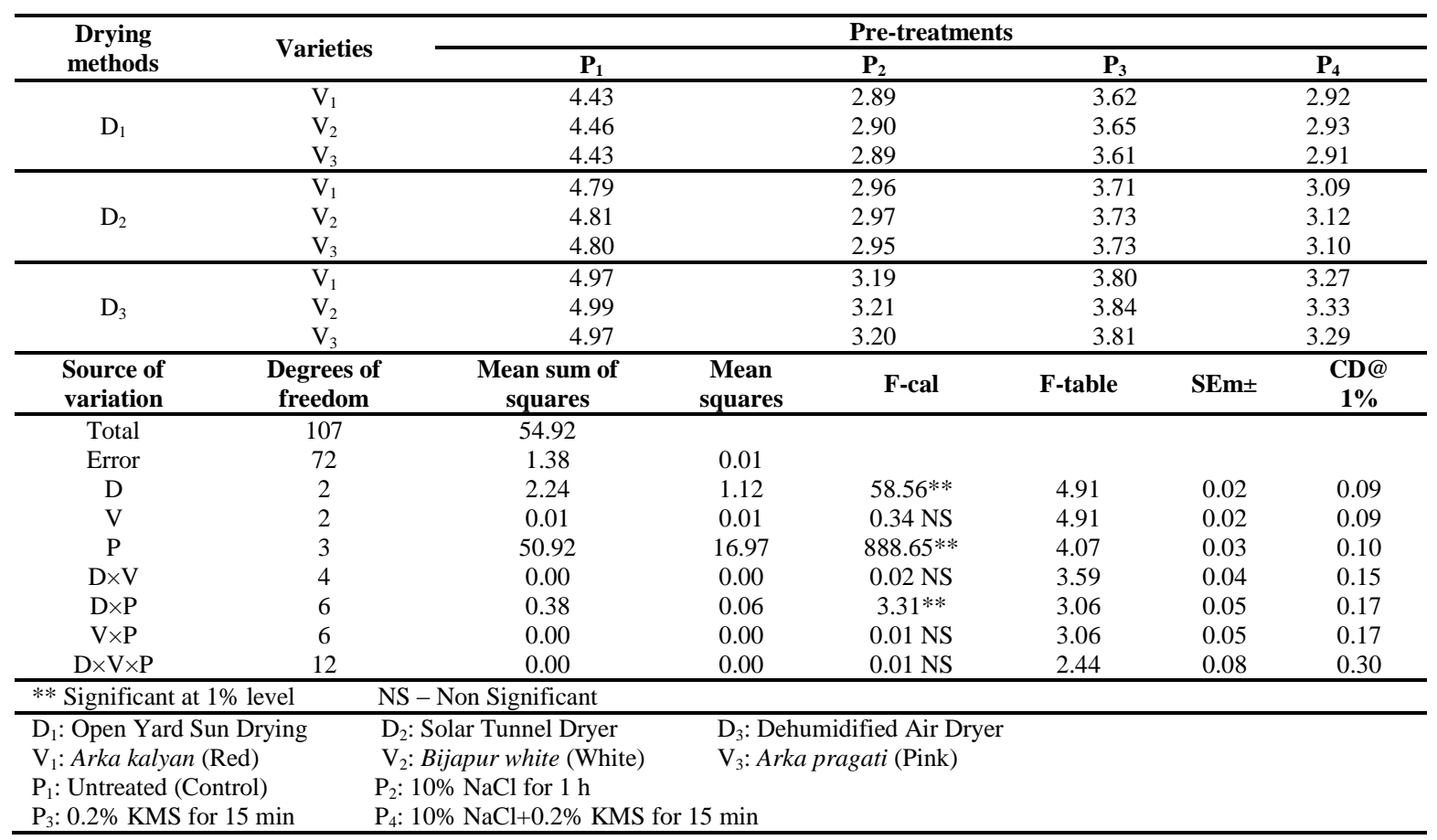

Table.3 Rehydration ratio of dehydrated onion slices obtained from different drying methods, varieties and pre-treatments rehydrated at $65^{\circ} \mathrm{C}$

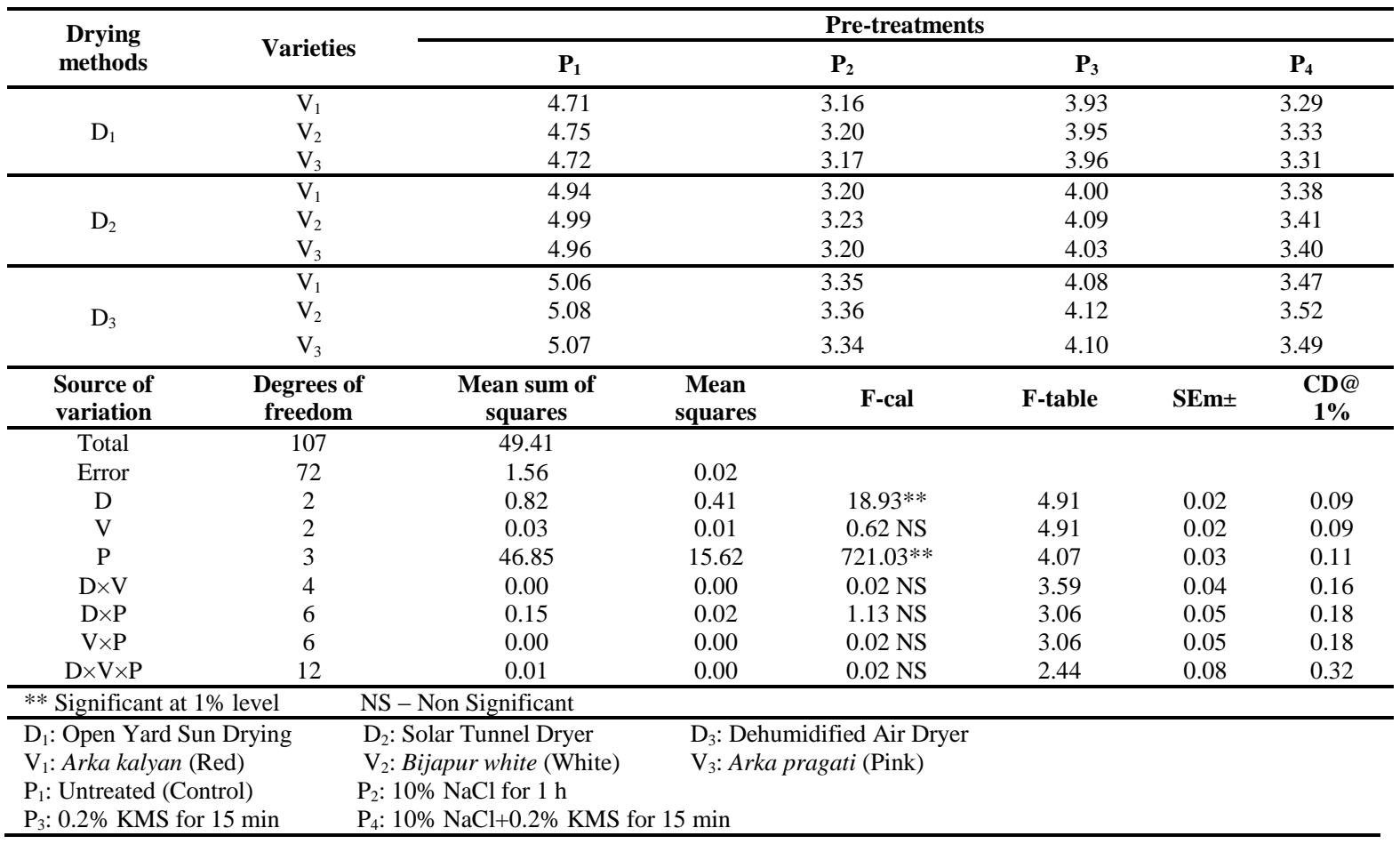


Fig.1 Rehydration ratio of dehydrated onion slices obtained from different drying methods, varieties and pre-treatments rehydrated at $25^{\circ} \mathrm{C}$ (D - Drying methods; V- Varieties)

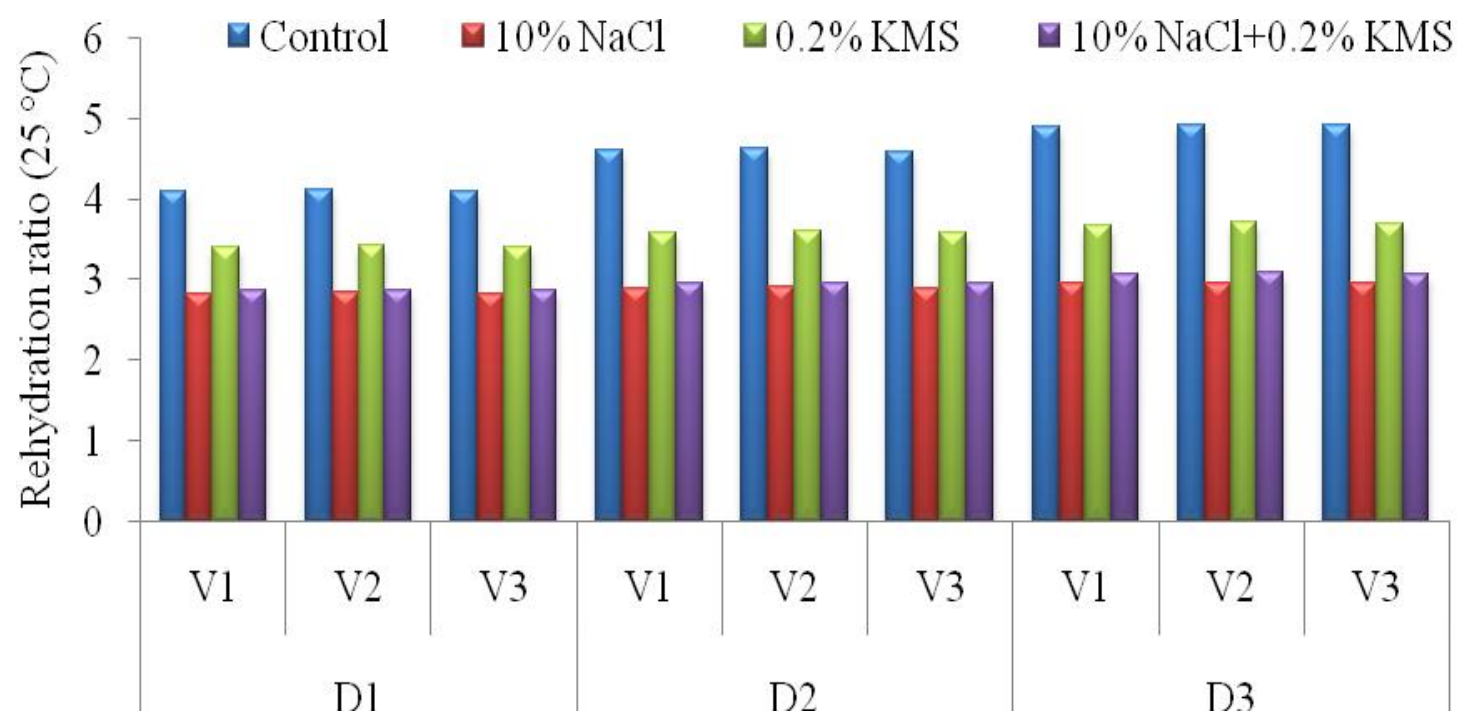

Fig.2 Rehydration ratio of dehydrated onion slices obtained from different drying methods, varieties and pre-treatments rehydrated at $45^{\circ} \mathrm{C}$ (D - Drying methods; V- Varieties)

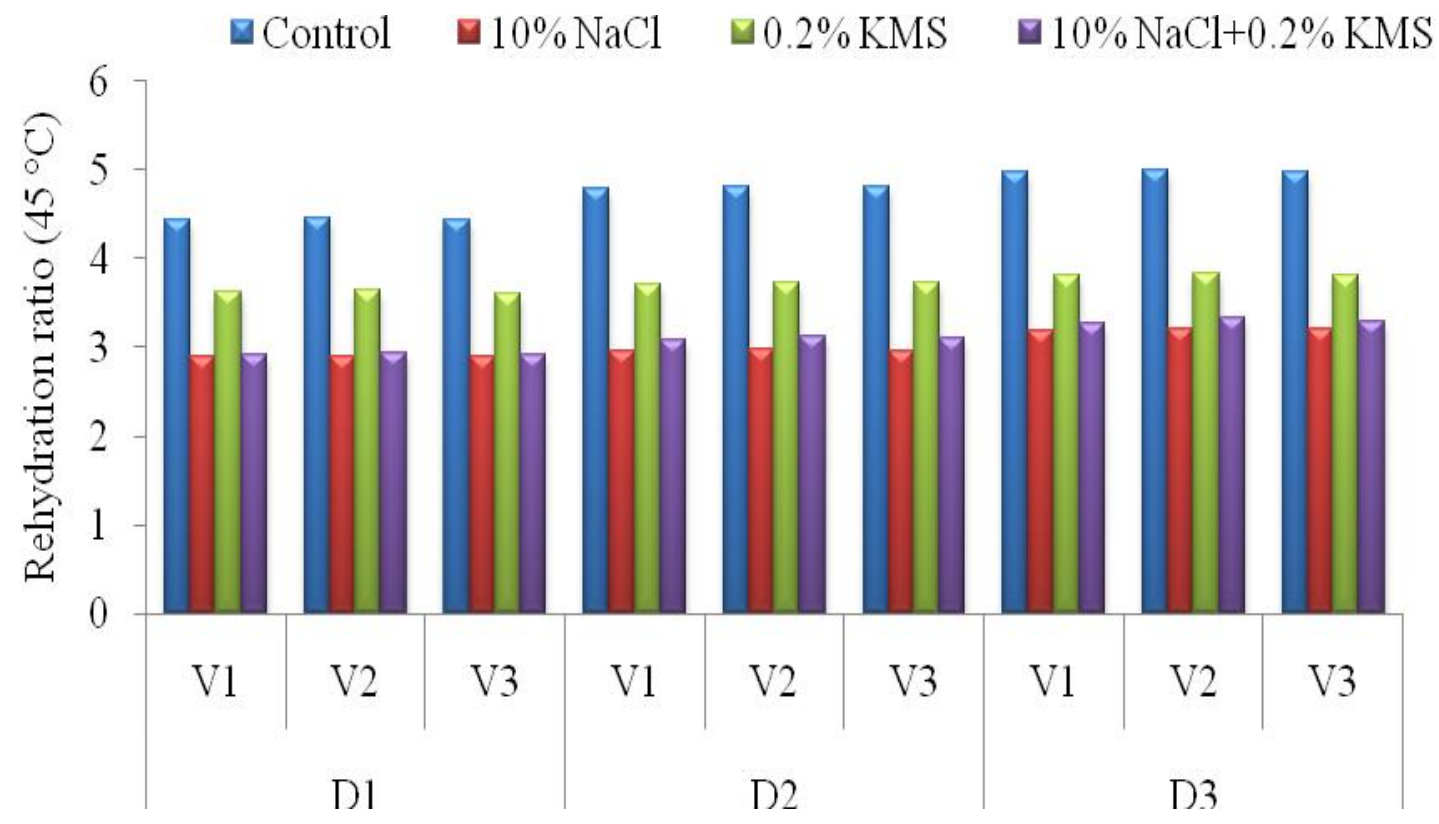


Fig.3 Rehydration ratio of dehydrated onion slices obtained from different drying methods, varieties and pre-treatments rehydrated at $65^{\circ} \mathrm{C}$ (D - Drying methods; V- Varieties)

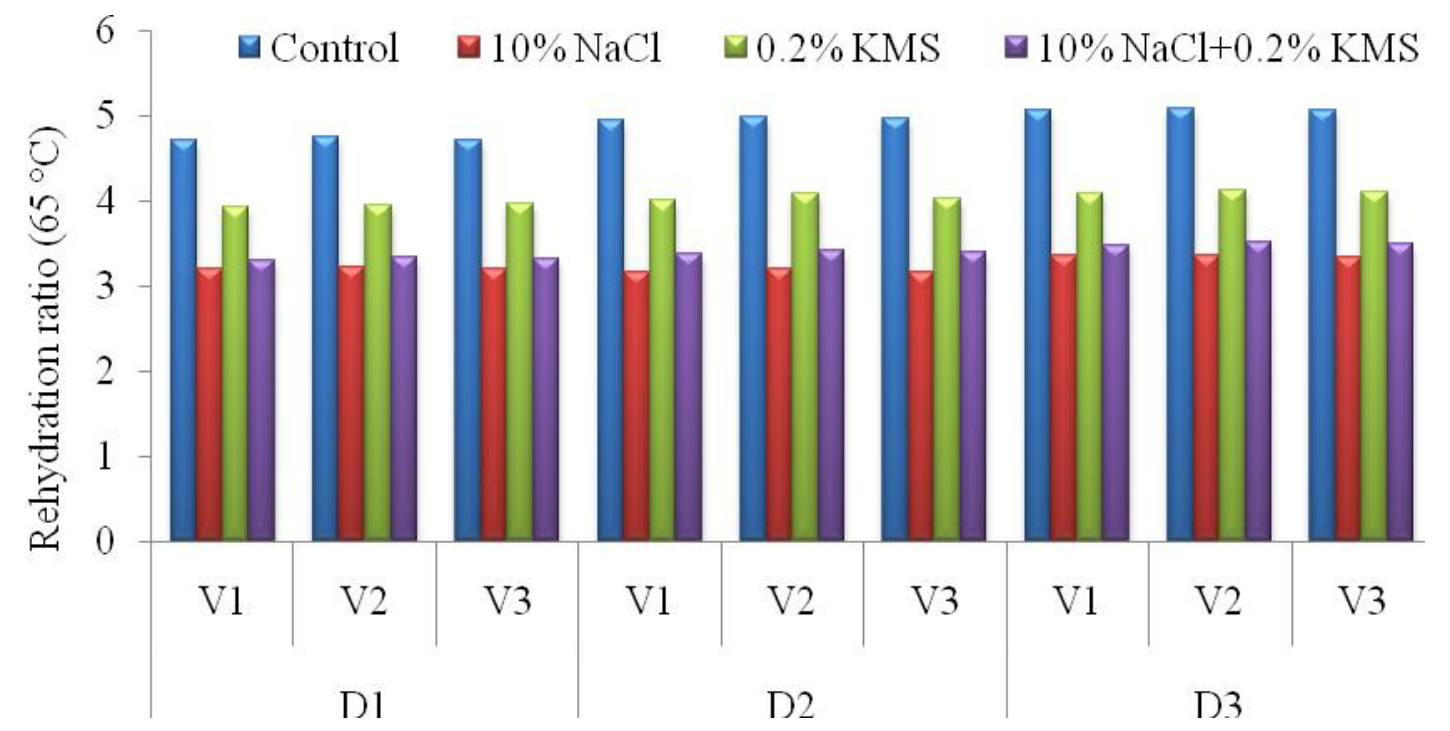

It was revealed from the results that the dehumidified air dried, untreated Bijapur white onion had higher rehydration ratio of 4.99 followed by dehumidified air dried, untreated Arka pragati and Arka kalyan onion as 4.97. The data indicated that in open yard sun drying, pre-treated with $10 \% \mathrm{NaCl}$ for Arka pragati and Arka kalyan onion had lowest rehydration ratio of 2.89 compared with all other treatments (Table 2). This is because, during rehydration, the absorbed salt may be dissolved in water, which decreases the weight of the sample and hence reduces the rehydration ratio (Sutar et al., 2007).

Lower values of the rehydration ratio were observed for osmotically pretreated samples than for the untreated (control). Lowering of the rehydration ratio due to osmotic pretreatment was also reported for other vegetables (Mazza, 1983). It may be due to higher salt gains during osmosis, salt occupies the pore spaces in the product and the pore spaces thus become unavailable to water during rehydration. Further, the coating of salt on the outer tissue of the product retards absorption of water by the inner tissues. Water absorption could also be hindered by the larger size of the hydrated salt molecules, which in turn would lower the rehydration ratio (Chopra and Verma, 1992).

Effect of different pre-treatments and drying methods on rehydration ratio of dehydrated onion slices rehydrated at 65 ${ }^{\circ} \mathrm{C}$

The rehydration ratio of Arka kalyan, Bijapur white and Arka pragati onion dried under different drying methods and pre-treatments were observed. The data obtained was analysed statistically and the individual factors i.e. drying methods and pre-treatments was found to be significant at $1 \%$ level $(\mathrm{P}<0.01)$ and the effect of different drying methods, varieties and pre-treatments on rehydration ratio rehydrated at $65{ }^{\circ} \mathrm{C}$ is depicted in Figure 3. It is observed that in 
open yard sun drying, the rehydration ratio of Arka kalyan, Bijapur white and Arka pragati onion was varied from 3.20-4.71, 3.23-4.75 and 3.20-4.72 among the different pretreatments. Similarly in solar tunnel drying, the rehydration ratio of Arka kalyan, Bijapur white and Arka pragati onion was varied from 3.16-4.94, 3.20-4.99 and 3.17-4.96, respectively. In case of dehumidified air drying, the rehydration ratio of Arka kalyan, Bijapur white and Arka pragati onion was varied from 3.35-5.06, 3.36-5.08 and 3.345.07 , respectively.

It was revealed from the results that, the dehumidified air dried, untreated Bijapur white onion had higher rehydration ratio of 5.08 followed by dehumidified air dried, untreated Arka pragati and Arka kalyan onion was 5.07 and 5.06. The results suggest that open yard sun drying, pre-treated with $10 \%$ $\mathrm{NaCl}$ of Arka pragati and Arka kalyan onion had lowest rehydration ratio of 3.20 compared with all other treatments as shown in the Table 3. This variation might be due to the long period of drying and the high temperature may contribute to a decrease in rehydration, because the product surface was destroyed and the destroyed pores allowed water reenter into the kernel (Mongpraneet and Tsurusaki, 2002). Similar results were found by Mitra et al., (2011) who reported that rehydration ratio was more in case of untreated samples i.e rehydration efficiency of untreated onion slices was more than that of brined onion slices.

The similar results were found by Debnath et al., (2004) who observed the same behaviour in their research related to rehydration of onion. Osmotic pretreatment resulted in decrease in the diffusion coefficient of water. This might be due to attributed to an increase in the proportion of ruptured and shrunken cells caused by osmotic treatment which in turn reduced the ability of dried onion tissues to absorb water. As temperature increased, the rehydration ratio increased slightly resulting in a proportional increase in the rehydration efficiency. This is because the faster drying caused less damage to the cells and as a consequence the water absorption efficiency was more.

The highest rehydration ratio were found to be 5.08 in untreated sample for Bijapur white onion dried in dehumidified air drying rehydrated at $65{ }^{\circ} \mathrm{C}$ as compared to rehydrated at 25 and $45{ }^{\circ} \mathrm{C}$. The pretreatments resulted in a decrease in the effective diffusion coefficient for water absorption and an increase in effective diffusion coefficient for solute infusion during rehydration. The pretreatment resulted in ruptured and shrunken cells in cellular structure, which, in turn, decreased the diffusion coefficient of water absorption. The increase in diffusion of solute during rehydration of dried onion subjected to osmotic pretreatment was due to leaching of enriched dry matter absorbed during osmotic pretreatment.

\section{Acknowledgement}

Dr. Udaykumar, Prof. and Head, AICRP on Post-Harvest Technology, Department of Processing and Food Engineering, College of Agricultural Engineering, University of Agricultural Sciences, Raichur (Karnataka) India.

\section{References}

Adam, E., Muhlbauer, W., Esper, A., Wolf, W. and Spiess, W., 2000. Quality changes of onion (Allium cepa L.) as affected by the drying process. Die Nahrung, 44(1): 32-37.

Andreotti, R., Tomasicchio, M. and Macchiavelli, L., 1981. Studies of rehydration properties of freeze-dried onion slices, Industria 
Conserve., 56: 87-91.

AOAC, 1990. Official Methods of Analysis, $15^{\text {th }}$ Edn., Association of Official Analytical Chemists, Arlington, VA. Method number. 930.04, pp 40, 69.

Augusti, K.T., 1996. Therapeutic values of onion (Allium cepa L.) and garlic (Allium sativum L.), Indian Journal Exp bill, 34(7): 634-40.

Block, E., Calvey, E.M., Gillies, J.Z. and Uden, P., 1997. Peeling the onion. In: Johns T, Romeo JT (eds) Functionality of food phytochemicals. Plenum, New York, pp 1-30.

Brewster, J.L., 1994. The biochemistry and food science of Alliums. Onions and Other Vegetable Alliums. CAB International, Cambridge, UK.

Chopra, C.S., and Verma, N.S., 1992. Osmovacuum drying of carrots. Beverage and Food World, 29(3): 7-9.

Debnath, S.J., Hemavathy, K.K. and. Rastogi, N.K., 2004. Rehydration characteristics of osmotic pretreated and dried onion. Journal of Food Engineering. 82(4): 304-310.

Gomez, K. A., and Gomez, A. A., 1976. Statistical procedures for agricultural research. Wiley International Science Publications, New York.

Lewicki, P.P., Witrowa-Rajchert, D., Pomaranska-Lazuka, W. and Nowak, D., 1998. Rehydration properties of dried onion, International Journal of Food Properties, 1(3): 275-290.

Mazza, G., and Lemaguer, M., 1980. Dehydration of onion: some theoretical and practical considerations. Journal of Food Technology, 15(2): 181-194.

Mitra, J., Shrivastava, S.L. and Srinivasa Rao, P., 2011. Onion dehydration: a review. Journal of Food Science Technology, DOI 10.1007/s13197-011-1369-1.

Mongpraneet, S., Abe, T., Tsurusaki, T., 2002. Accelerated drying of welsh onion by far infrared radiation under vacuum conditions. Journal of Food Engineering, 55(2): 147-156.

Nuutila, A.M., Puupponen-Pimia, R., Aarni, M., Oksman-Caldentey, K.M., 2003. Comparison of antioxidant activity of onion and garlic extracts by inhibition of lipid peroxidation and radical scavenging activity. Food Chemistry, 81(4): 485-493.

Oliveira, A.R.F., and Ilincanu, L., 1999. Rehydration of dried plant tissue: basic concepts and mathematical modeling, in Processing Foods, Quality, Optimization and Process Assessment, Oliveira, A.R.F. and Oliveira, J.C. (eds)., CRC Press, London, UK, pp 201-227.

Stavric, B., 1997. Chemopreventive agents in foods. In: Johns T, Romeo J.T. (eds) Functionality of food phytochemicals. Plenum, New York, pp 53-87.

Sutar, P.P., and Gupta, D.K., 2007. Modeling fluidized bed drying of osmotically dehydrated onion slices and product quality evaluation. American Society of Agricultural and Biological Engineers, 51(2): 567-572.

\section{How to cite this article:}

Goudra Pramod Gouda, C.T. Ramachandra, Udaykumar Nidoni, H. Sharanagouda, P.F. Mathad and Roopa Bai, R.S. 2017. Rehydration Characteristics of Dehydrated Different Onion Slices. Int.J.Curr.Microbiol.App.Sci. 6(10): 2684-2692. doi: https://doi.org/10.20546/ijcmas.2017.610.316 